\title{
"Vesperais Literárias": A Semana de Arte e LiTERATURA, RIO, 1921
}

\section{"Vesperais Literárias": Week of Literature and Arts, Rio, 1921}

\author{
Stela de Castro Bichuette
}

\begin{abstract}
RESUMO
É objetivo deste artigo apresentar uma série de conferências literárias idealizadas pelo autor fluminense Adelino Magalhães (1887-1969), no Rio de Janeiro, em 1921. As "Vesperais Literárias", como ficaram conhecidas, aconteceram entre julho e setembro daquele ano; tinham como proposta principal a valorização da literatura brasileira através de autores importantes do cânone literário nacional. Embora realizada em uma época de agitação estética e literária, muitos dos autores eleitos para a homenagem poderiam estar em descompasso com as mudanças literárias do momento. A atitude de homenageá-los demonstra que, para o grupo que girava ao redor de Magalhães, não havia nenhum tipo de problema em valorizar e conviver harmoniosamente com aqueles escritores que fizeram parte da sua formação humanística e literária.
\end{abstract}

Palavras-chave: Adelino Magalhães, Modernismo, "Vesperais Literárias".

* Universidade Estadual do Centro Oeste (Unicentro). 


\begin{abstract}
This paper aims to present the literary lectures "Vesperais Literárias", idealized by Adelino Magalhães (1887-1969), in 1921, in Rio de Janeiro. The "Vesperais Literárias" took place between July and September of that year and had as main purpose to value the important authors of the Brazilian canon. Although they were hold in years of aesthetic and agitation, the "Vesperais Literárias" honored authors that could be at odds with literary changes. The attitude of honoring those dead authors demonstrates that for Magalhães' group they still had importance to the national literature.
\end{abstract}

Keywords: Adelino Magalhães, Modernism, "Vesperais Literárias".

\title{
1. 1921: HISTÓRIA E LITERATURA
}

O contista Adelino Magalhães, lembrado e ocultado na história do Modernismo brasileiro, sempre se preocupou com a gênese desse movimento, haja vista o número de crônicas, de entrevistas e de estudos sobre o tema presente em seu arquivo pessoal. A partir de uma dessas crônicas do arquivo do escritor, "Quando teria começado o Modernismo", sem datação, Brito Broca articula que aquele movimento foi o caminho lógico da literatura e que, portanto, não surgira "repentinamente, como uma eclosão de forças até então ignoradas", e ainda que o movimento "foi consequência lógica de uma atitude há muito pressentida, e se a S.A.M. marca o início 'oficial' [...], é difícil precisar quando ele teria verdadeiramente começado" (BROCA, s/d). É essa atitude de desconfiança sobre o surgimento do modernismo que permeia todo o arquivo pessoal de Adelino Magalhães, me servindo de reflexão para entender o surgimento das "Vesperais Literárias", de 1921, um dos projetos mais ambiciosos do autor e objeto de estudo desse trabalho.

O ano de 1921 não entrou para a história literária brasileira como aconteceu com 1922. Esse último ficou conhecido e é lembrado até hoje como um divisor de águas: de um lado, a literatura mofada, acadêmica, envelhecida, tradicional; de outro, a literatura de destruição, de combate, de novos valores estéticos. Com um olhar menos eufórico sobre os anos posteriores a 22 e mais brando sobre os anos anteriores a ele, pode-se dizer que 21 tem muito a mostrar. Os acontecimentos desse ano são importantes para o entendimento do modernismo brasileiro, do modernismo carioca e, mais 
especificamente, do grupo de Adelino Magalhães, posteriormente fundador do periódico modernista Festa.

No campo histórico e político, uma das maiores preocupações, em 1921, no Rio de Janeiro - então capital federal -, dizia respeito aos preparativos para o grande evento que iria ser comemorado no próximo ano, o Centenário da Independência. Não seria de se estranhar a celeuma causada em volta de tão especial data, pois seria a concretização do desejo de modernidade e de civilidade que começara anos antes com as reformas urbanas da Cidade-Capital.

O Rio tinha se embelezado com a construção das enormes avenidas abertas por Pereira Passos e o povo já tinha sido, ao menos em parte e a duras penas, adestrado dentro de um ideal de higienização proposto de acordo com ideais almejados pela elite, a qual buscava quase uma limpeza étnica. Seria de se esperar, então, uma grande festa para celebrar as glórias da Independência e, com ela, coroar de vez a assertiva de ordem e de progresso.

A comissão responsável pelos preparativos do evento tinha em mente a construção de um enorme pavilhão para receber o que os vários países convidados para as festividades trouxessem para solo brasileiro - um pouco de sua cultura nativa. Para tanto, ficou decidido que o Morro do Castelo seria destruído e, em seu lugar, se levantaria o Pavilhão de Exposição Internacional do Centenário. A construção foi sendo acompanhada tijolo a tijolo pela impressa da época; cada pá de areia era reportada com grande satisfação pelos homens das letras, pois lhes rendiam assuntos que eram tratados, muitas vezes, de forma humorística, deixando transparecer o quanto tudo aquilo era dispendioso para a população em geral.

Nos campos literário e cultural, 1921 trouxe mortes emblemáticas. A notícia da morte de Paulo Barreto, o João do Rio, causou uma grandiosa comoção na população carioca. Milhares de pessoas acompanharam seu cortejo fúnebre; pelas fotos nos jornais da época, é possível perceber com exatidão o valor da perda do escritor. As pessoas chegavam a subir às árvores para poder prestar suas últimas homenagens ao finado. Desaparece, também, nesse mesmo ano, em Minas Gerais, Alphonsus de Guimaraens, poeta simbolista aclamado pela geração modernista, a qual reconhecia naquela escola o primeiro rompimento com o academicismo parnasiano - sendo, por isso, fora considerada como o gérmen do modernismo.

É também em 1921 que Oswald de Andrade, no artigo intitulado "O meu poeta futurista", apresenta Mário de Andrade (somente conhecido pelos jovens modernistas) ao público. Neste artigo, Oswald de Andrade comenta o poema "Tu", que posteriormente foi inserido dentro de Pauliceia Desvairada, de 1922. Conta Mário da Silva Brito (1978), em A História do Modernismo Brasileiro, que o artigo de Oswald de Andrade envolve Mário 
de Andrade em um verdadeiro escândalo devido ao adjetivo "futurista" do título, comparando os vexames sofridos pelo paulistano aos sofridos alguns anos antes, em 1917, por Anita Malfatti em nome da pintura. Brito (1978, p.230) informa que "tão forte foi a celeuma provocada nas rodas literárias, que de uma hora para outra o nome de Mário de Andrade, até então só conhecido dos 'novos', toma conta da cidade, ganha uma popularidade, uma celebridade espantosa". Ainda segundo Brito, (1978, p.232):

O escândalo foi tão fortemente sentido, cala tão fundo o adjetivo "futurista", com que o classificaria Oswald de Andrade, que os pais de vários alunos do professor resolveram, cautelosa e precavidamente, retirar seus filhos sob os cuidados de tal mestre - um maluco e perigoso "futurista".

É no vácuo desse sucesso nascente que Mário de Andrade escreve a famosa série de artigos "Mestres do Passado", no Jornal do Commércio, também em 1921, referindo-se aos poetas parnasianos Francisca Júlia, Raimundo Correia, Alberto de Oliveira, Olavo Bilac e Vicente de Carvalho.

Nesse mesmo ano, em 5 de novembro, é noticiado, no número 698 da Revista Careta (Rio de Janeiro), o recebimento da terceira edição de Juca Mulato, de Minotti Del Picchia. A nota literária, sem autoria, vem com uma ponta de ironia, que não chega a ser novidade, haja vista o conteúdo humorístico da revista; ela zomba do prefácio do livro, feito por Julio Dantas. Na nota, o autor diz que o prefácio de Dantas, aclamando Picchia como um dos maiores poetas do Brasil, não deve ser considerado muito crível, uma vez que o "Sr. Dantas tem a louvável mania de falar bem de quase todos os poetas do Brasil" (REVISTA CARETA, 1921, s/p)

Coincidentemente, nesse mesmo exemplar de Careta, na coluna "Vida Alheia", surgem dois comentários assinados sob o pseudônimo de Y-Juca-Pirama ${ }^{1}$. o primeiro, sob o título de "Graça Aranha", anuncia a volta do escritor de Canaã ao Brasil; logo, em seguida, a nota "Futurismo" comenta o fracasso de uma ópera de Marinetti, na Europa, vaiada tanto em Roma quanto em Paris. Continua, portanto, o embate entre o que era ser futurista e o que era ser modernista. Em literatura, a nota continua, não há espaço para o futurismo no Brasil, "em São Paulo, cidade mais influenciada pela Itália, um grupo de independentes realistas pretendem implantar o futurismo na moderna geração de escritores e poetas" (Y-JUCA-PIRAMA, 1921, s/p). O 
cronista afirma que querem fazer de Oswald de Andrade o porta-bandeira brasileiro da escola italiana; no entanto, afirma que não é necessária nenhuma escola internacional para que os autores brasileiros criem maravilhas de arte, sendo, portanto, inaceitável o auxílio de uma escola italiana que nada nos diz.

De resto, o que se pode concluir é que os ideais modernistas circulavam no campo das ideias a partir de vários vetores de possibilidades. Alguns dos modernistas cariocas, que se agrupavam em torno da figura de Magalhães, propunham uma revolução menos gritante. Desse comportamento, pode ser percebido os diferentes projetos entre os modernismos, cada um com suas nuanças próprias. Será uma vertente diferenciada do modernismo que se viu no evento das "Vesperais Literárias".

\section{Adelino Magalhães e o grupo de $F$ Esta}

Um erro que se pode cometer ao interpretar tanto a vida quanto a obra de Adelino Magalhães é vinculá-lo constantemente ao grupo de Festa, isto é, ver sua obra anterior à revista de acordo com o espiritualismo da publicação. A amizade entre Adelino Magalhães e os outros fundadores do periódico - a saber, Andrade Muricy, Tasso da Silveira e Murillo Araújo - já vinha de longa data, especificamente desde as revistas Árvore Nova, Terra do Sol e América Latina. É interessante enfatizar que Adelino Magalhães não era mais um no grupo da revista. A participação do escritor era muito importante, pois ele já vinha de um passado de publicações literárias e de editoração de revistas.

Quando fez parte do grupo de Festa, o escritor já havia lançado o grosso de sua obra. Sua primeira publicação, Casos e Impressões, tinha aparecido com relativo sucesso em 1916; desde então, seu nome tornou-se conhecido nas rodas literárias cariocas, principalmente pelas experiências estéticas inovadoras e diferenciadas em compasso com as inovações vanguardistas do começo do século XX. Suas narrativas são desconcertantes, povoadas por toda a sorte de personagens em conflitos existenciais que sofrem uma angústia quase neurótica diante do mundo caótico e degradante que apresentava o novo século. Tudo isso com uma escrita fragmentada e instantânea que muitas vezes não foi entendida pelos seus contemporâneos, sendo alvo de críticas duras por parte dos conservadores. Isto posto, é interessante enfatizar que Adelino Magalhães, portanto, já gozava de prestígio literário muito antes da revista Festa: é um equívoco que a crítica literária especializada continue a caracterizá-lo somente à luz dessa publicação. Assim sendo, em 1927, quando a revista modernista saiu pela primeira vez, o 
Centro de Cultura Brasileira (C.C.B.) - e, junto a ele, o evento das "Vesperais Literárias" - já estava findando suas atividades. Portanto, a meu ver, Adelino Magalhães não é herdeiro de Festa: ou seja, não é o autor que deve pagar tributo à publicação, mas o inverso, a publicação que parte da necessidade do vínculo com o escritor que era nome conhecido e reconhecido.

Dessa maneira, não é temerário afirmar que muitos dos nomes de Festa já haviam então, de certa forma, em maior ou menor grau, participado dos dois projetos anteriores de Adelino Magalhães: "As Vesperais Literárias", em 1921 e a fundação e funcionamento do C.C.B., entre 1923 e 1927. Vale lembrar que o evento das "Vesperais Literárias" foi o carro abre-alas do que viria ser o Centro de Cultura Brasileira, fundado oficialmente em 1923. O centro funcionou por sete anos, dentro dos quais, segundo Adelino Magalhães (1953, s/p), foi mantido "o fogo sagrado da legítima cultura nacional, sustentado, aliás por gente de valor, novos e antigos, sem nenhum preconceito de grupos e aliciando artistas e até cientistas de várias matizes intelectuais. Novíssimos ombreavam com acadêmicos, naquelas 'festas de arte'." (grifos meus).

Adelino Magalhães tinha como hábito recortar pedaços de revistas, de jornais e de periódicos pelos quais se interessava e colar esses recortes no que chamo de cadernos-arquivos. Vale ressaltar que em seu arquivo pessoal há poucas referências à revista Festa. São poucas as lembranças sobre o periódico nos cadernos; a grande maioria refere-se ao C.C.B, às "Vesperais Literárias" e ao embate nos jornais e periódicos entre os modernismos carioca e paulista.

Nesse sentido, seria muito mais proveitoso para a história da literatura conhecer e estudar Adelino Magalhães pelos seus dois projetos já mencionados do que somente vê-lo com um dos participantes de Festa.

\section{As "Vesperais Literárias" e as REDEs de sociabilidade carioca}

Adelino Magalhães, ao planejar as suas "Vesperais Literárias" em 1921, estava bem consciente do que propunha. Ele almejou, para essas semanas de literatura, de arte e de música, estudos sobre vultos importantes da história da literatura brasileira. Muitos desses autores que seriam estudados e homenageados por Magalhães estavam, em maior ou menor grau, em descompasso com as ideias literárias mais radicais do começo do século $\mathrm{XX}$. No entanto, Magalhães demonstrou que não tinha nenhum tipo de problema em valorizar e conviver harmoniosamente com aqueles escritores que fizeram parte de sua formação humanística e literária. Não era uma vergonha poder homenageá-los. Adelino Magalhães não foge a isso. Sua produção 
está totalmente ligada à sua visão de mundo - pois para o escritor, o novo e o velho eram somente faces de uma mesma moeda. É o próprio Magalhães (1963, p. 754) quem, ao refletir sobre o assunto, deduz:

Afinal, "novo" acaba sendo o velho de que nós vamos tendo conhecimento. Tão "futuro" me pode ser o que já se passou, e que vou saber. Por isso, talvez, é que não sinto nada de ancestral na paisagem pré-histórica: à medida que se me vai abrindo ela, tenho a impressão de que vou andando para diante, pelo tempo.

Nesse clima de grupos que se rivalizavam de acordo com os ideais da arte modernista, várias agremiações se destacam, para que os laços de cooperação tornassem a vida intelectual e literária menos árdua - afinal, é através dessas relações que se estabeleciam, para os escritores, ligações duradouras (ou não) no cenário intelectual, garantindo-lhes a permanência no meio artístico e a publicação de suas obras, o que, naturalmente, eles almejavam.

Os encontros literários (ou ditos saraus literários) não eram nenhuma novidade dentro da sociedade carioca. Eram um hábito herdado do Romantismo, que teve nos salóes franceses seu grande modelo. As portas das casas de grandes mecenas, de alguns escritores ou de pessoas endinheiradas da sociedade - desejosas por serem reconhecidas mais pelo seu gosto erudito do que pela fortuna que possuíam - se abriam a esses meetings que tinham, à época, como pano de fundo as apreciações literárias, ainda que, obviamente, não deixassem de ser um lugar de sociabilidade entre os donos dos salões e seus convivas.

No Rio de Janeiro, um famoso salão literário, de dona Laurinda Santos Lobo, a Vila Murtinho, situado em Santa Teresa, abria suas portas para os concorridos encontros à tarde com um serviço de chá e com discussões literárias que se estendiam até a noite, quando se iniciavam os bailes; junto a eles, surgia um ambiente mais boêmio. Também no Rio de Janeiro era muito procurado e comentando na imprensa da época os encontros na casa do escritor Coelho Neto. Tal salão não tinha o charme do salão de Santa Teresa, mas fazia parte também do caráter mundano das festas literárias cariocas. Já em São Paulo, o salão mais conhecido e mais lembrado até hoje é a Villa Kyrial, do mecenas e poeta José de Freitas Valle.

A par disso, o que haveria de diferente entre as declamações e apreciações culturais dos saraus nas casas particulares e as reuniões literárias de Adelino Magalhães, para que estas últimas fossem tão noticiadas pela impressa, sendo eleitas, anos depois por Wilson Martins (1978), como a "Semana de Arte Abortada"? 
Em primeiro lugar, por acontecerem nos salões da Biblioteca Nacional, as "Vesperais Literárias" perdiam, até certo ponto, o caráter de encontro social e privado, passando a ter, oficialmente, um propósito especificamente literário. Isso quer dizer que o espaço legitimado da Biblioteca Nacional já era destinado à leitura; portanto, não cabiam os bailes. Por outro lado, talvez por não serem vinculadas a um "dono" do salão, as discussões pudessem ter maior liberdade quanto à tratativa de temas, autores e livros, sem a obrigação de agradar a esse ou aquele convidado ou de serem proferidas palestras de acordo com o mecenas em questão. Por isso, o grupo realizador, ao escolher um espaço público, deu aos convidados a permissão implícita de que poderiam, sem medo de ofensas diretas ou sem medo de arruinar a noite cerimonial, fazer qualquer tipo de interferência nas palestras, fosse para concordar ou para refutar.

No dia 18 de setembro de 1921, Nestor Vitor escreve o artigo "Um pouco da crônica da vida literária”, no Jornal dos Debates, de São Paulo, tendo como tema a vida literária no Rio de Janeiro e, mais particularmente, referindo-se às "Vesperais Literárias", isto é, aos encontros literários realizados todas as tardes de sábado, entre julho a setembro, nos salões da Biblioteca Nacional. O artigo fora escrito após o término da última vesperal e fazia um balanço acanhado dos encontros, enfatizando a maneira pela qual as reuniões entre os "novos" e os grandes vultos da história literária brasileira aconteceram. Sobre os encontros, escreve Vítor (1972, p.451):

Os moços vivem hoje, como eu dizia, tratando muito bem os acadêmicos, mas estes, por sua vez, ainda os mais caracteristicamente "velhos", quero dizer, mais genuinamente parnasianos, ou naturalistas, têm de mostrar-se tolerantes até com a memória dos que são verdadeiros ídolos desses jovens estetas-políticos.

As "Vesperais Literárias" começam a ser noticiadas como um movimento dos "novos" que não querem esquecer os antigos mestres. Para o grupo de Magalhães, os "Mestres do Passado" se foram. Porém, deixaram seu legado de contribuição para a história da cultura brasileira e, portanto, deveriam estar presentes como forma de continuidade do tradicional, exatamente para que houvesse renovação.

Dessa forma, o artigo de Vítor (1972) enfatiza a relação entre os "novos" e os "velhos", ou entre os progressistas e os conservadores, ou entre os modernistas e os passadistas. Aqui, o que não se pode perder de vista é que a dualidade - tão nítida que algumas histórias literárias insistem em mostrá-la e alguns livros didáticos insistem em perpetuá-la - não é tão óbvia quando colocada no continuum de seu tempo. É certo igualmente que 
a linha ideológica entre os autores desse período é tênue. As colocações de Vítor (1972) revelam o encontro dessas duas gerações, ora amistoso ora com uma ponta de hostilidade. Para exemplificá-lo, o crítico relatou que quem fizera o discurso à memória do simbolista Emiliano Perneta (quando da homenagem, em 19 de abril de 1921, aos seus três meses de falecimento) fora nada menos que o parnasiano Alberto de Oliveira.

A homenagem a Perneta corria bem, com louvores simbolistas e com o acolhimento compreensível da ala dita conservadora, até que Bueno Monteiro colocu em pauta o rigor acadêmico e envelhecido de certos poetas, o que levou Vítor (1972, p.452) a questionar de que "necessidade tinham aqueles rapazes de ver Alberto meio conturbar-se na sua linha tão simpaticamente olímpica, Rodrigo ficar mais vermelho do que costuma ser na moldura ainda quase persistente loura barba que lhe vai tão bem e Goulart remexer-se na cadeira?"

Certo é que tal contratempo aconteceu mais por galhofa juvenil do que por vontade de um verdadeiro embate entre ideologias estéticas opostas, uma vez que o clima era verdadeiramente amistoso entre os convidados - a propósito, os antigos se deixavam levar muitas vezes pelos impulsos dos novos para que não perdessem o contato com o tempo vindouro mesmo que isso lhes custassem algumas amolações.

Aqui vale retornar à impossibilidade do dualismo muitas vezes retratado de forma emblemática pelos estudos literários, principalmente se tivermos em mente os círculos de sociabilidade dos escritores que teciam suas redes na capital federal no começo do século XX. Não eram relações estanques e eternas, porquanto mudavam de direção de acordo com os ideais de afetividade que dominavam os relacionamentos. Por isso, as colocações de Murari $(2007, \mathrm{~s} / \mathrm{p})$ são esclarecedoras, quando aponta que

as caracterizações da intelectualidade brasileira da belle époque a partir das oposições progressistas X conservadores, derrotados X vencedores, literatura oficial X pré-modernismo apresentam soluções atraentes para aqueles que buscam compreender o período, à medida que permitem delimitar com bastante clareza o espaço ocupado por cada intelectual no meio letrado, definindo sua filiação a correntes estéticas, políticas e ideológicas. O problema pode estar, justamente, na excessiva generalização da qual depende este procedimento.

É nessa linha de pensamento coerente que nasce as ideias das "Vesperais Literárias". Por sua figura tímida, foi com surpresa que muitos receberam a notícia de que as tardes literárias na Biblioteca Nacional tinham 
sido pensadas por Adelino Magalhães. Sobre o assunto, o escritor, em uma entrevista de 1953, também presente em seu arquivo, afirma que, embora tenha vivido apartado da vida literária e longe das "igrejinhas", não era contrário a elas, uma vez que representam a reunião de elementos da mesma tendência - no entanto, elas são "censuráveis quando as lutas entre elas tomam a forma de mesquinhas lutas de acusações ou depreciações a outros grupos" (MAGALHÃES, 1953, s/p).

Nessa mesma entrevista, Adelino Magalhães reafirmou a necessidade de valorizar os escritores, levando em conta a valorização do passado, que sempre esteve no cerne das "Vesperais Literárias". Para exemplificar, o autor trouxe para a conversa o nome de Coelho Neto, poeta e romancista, que foi por muito tempo símbolo do passado embolorado que precisaria ser extinto:

Muita gente de seu tempo achava o prestígio de Coelho Neto exagerado. Pela minha parte, apreciava o romancista do qual aliás recebi gentilezas, elogios amigos, coisa que naturalmente muito me sensibilizava. Atualmente, vejo com pesar uma campanha com fim de anular o valor do romancista de Inverno em Flor, o qual, a meu ver, tem qualidades estilísticas e de observação perfeitamente perduráveis. (MAGALHÃES, 1953, s/p)

\section{A programaçÃo das "Vesperais Literárias"}

O evento das "Vesperais Literárias" é importante dentro dos estudos sobre Adelino Magalhães porque será através delas que o seu projeto de união entre o novo e o velho toma forma. Isso significa que as tardes de 21 fomentariam as discussões sobre a cultura brasileira, sobre o nacionalismo e sobre o futuro do país. Elas se tornaram o aperitivo para o sonho maior do escritor, que era o de pensar a cultura, a nacionalidade e a brasilidade dentro de um local específico - que foi, posteriormente, o C.C.B.

A par de tudo isso, a primeira chamada na imprensa da época para as palestras que movimentariam o inverno carioca de 1921 apareceu na revista Careta, de 11 de junho daquele ano. 0 título divulgado: "As palestras dos Novos". Nessa primeira publicidade das "Vesperais Literárias", o organizador das palestras e seus convivas são nomeados "intelectuais dos mais modernos". Deve ficar claro que o adjetivo moderno implica aqueles escritores que começaram a romper, em sua escrita, com a literatura predominante naquele momento, qual seja, a literatura parnasiana preocupada, sobretudo, com a linguagem bem trabalhada. Nota-se também que esse mesmo adjetivo não dever ser confundido com o termo modernista: aqui os 
vocábulos assumem diferentes concepções, uma vez que o termo modernista ainda não era utilizado no sentido de designar autores que buscavam uma ruptura total com o velho modelo literário.

Como eram feitas pelos novos autores, nada mais coerente que as "Vesperais Literárias" tratassem de escritores modernos, sendo imaginadas como apresentação dessas vozes inéditas para o grande público. Esse entendimento foi o do repórter que escreveu a nota - ele noticiava que seriam lidos, em julho, na inauguração da empreitada, os versos de Tasso da Silveira, Murillo Araujo e Raul de Leoni.

As "Vesperais Literárias" também foram amplamente divulgadas na Revista Fon Fon, de 25 de junho de 1921. O mesmo tom de modernidade que se via em Careta era também adotado nesse outro periódico. De diferente, apenas a ampliação dos nomes dos participantes (como Barreto Filho e Duque Costa) e a confirmação do local de realização, a Biblioteca Nacional. A edição de 25 de junho de 1921 de Fon Fon, também trouxe maiores informações sobre as tão faladas palestras: a data de início, 9 de julho, bem como as atividades, que contariam não somente com a leitura de poemas de vozes masculinas - haveria uma parte destinada a poetisas e escritoras femininas.

Após a notícia do dia 25 de junho, as "Vesperais Literárias" voltaram a ser noticiadas pela revista Careta, em 23 de julho. Nessa divulgação, mais uma vez, os organizadores são chamados de "novos"; concede-se a informação de que eles homenageariam poetas e escritores já mortos. Para a próxima reunião, do dia 30 de julho, os nomes escolhidos foram de B. Lopes, Augusto dos Anjos, Mario Pederneiras e Adolfo Caminha.

A escolha de determinados nomes em detrimentos de outros não podem ser ignoradas, pois todas as seleções pressupõem exclusões. As escolhas feitas por Magalhães não são aleatórias e muito menos ingênuas. $O$ vemos é a escolha de três poetas simbolistas, o que remete a duas questões importantes: primeiramente, o grupo de Adelino Magalhães mais tarde seria considerado neo-simbolista de fundo espiritualista, ainda que a obra do escritor, anteriormente a 1930, fuja desse rótulo.

A outra questão que pode ser levantada dessa seleção é a de que o Simbolismo foi a única escola poupada aos ataques furiosos dos modernistas paulistas. Disso é permitido fazer a seguinte analogia de que ambos os grupos (os "novos" cariocas e os "futuristas" paulistas), muitas vezes em polos opostos, faziam parte de um mesmo projeto. Um projeto cauteloso dos cariocas e um projeto mais audacioso dos paulistas.

A seleção dessa segunda tarde literária fecha com Adolfo Caminha, escritor de Bom Criolo e representante do naturalismo, estética que já caía em desuso desde os primeiros anos do século XX. O nome de Caminha trouxe para as primeiras "Vesperais Literárias" o sopro do passado, pois seu grupo 
idealizador não gostaria que este fosse esquecido; ele é a voz destoante do grupo do segundo encontro, o qual, no entanto, também construiu uma trajetória literária brasileira de valor: portanto, não dever ser esquecido ou mesmo depreciado.

Ainda sobre a vesperal do dia 30 de julho, a revista Fon Fon, (número 31,1921 ) solta a mesma nota, complementando com a informação dos oradores. O escritor José Oiticica falaria sobre Augusto dos Anjos, Brenno Arruda discorreria sobre Mário Pederneiras ${ }^{2}$ e Rodolpho Machado comentaria a obra de B. Lopes. Nenhuma das palestras desse dia pode ser localizada no arquivo de Adelino Magalhães, excetuando aquela em homenagem a Raul Pederneiras, foi publicada na íntegra pela mesma revista Fon Fon, da qual o escritor fora colaborador assíduo.

A leitura da homenagem a Raul Pederneiras revela um fato interessante: a presença feminina nas "Vesperais Literárias". 0 orador Claudio Ganns (1921. s/p) mantém contato constante com seus ouvintes, dirigindo-se especificamente às mulheres, a maioria do público. Diz o interlocutor: "um auditório talvez em sua maioria feminino" ou "acabais de ver, minhas senhoras".

Nestor Vítor (1972, p. 451), em seu inventário sobre as "Vesperais Literárias" também enfatiza a presença feminina ao longo das conferências: "O salão tem ficado tão cheio, tão cheio que é preciso chegar-se antes das quatro para obter bom lugar. Boa parte do elegante Botafogo tem estado ali de pé firme, dando a tudo graça incomparável que só o elemento feminino é capaz de dar."

Continuando, o discurso de Gans (1921) sobre Pederneiras mostrou muito bem as disputas entre os "velhos", simbolizados pelo Parnasianismo na fala do orador, e os "moços", que aspiravam a uma nova estética, neste caso o Simbolismo. O que chama atenção é o tom ameno com que se faz a alusão às duas extremidades estéticas: não há negação ou o desejo de esquecimento. O passado parnasiano é visto como benevolência e nostalgia. Diz o palestrante: "a deusa marmórea dos antigos já não tinha entrada no coração dos moços, seduzidos por uma outra alada divindade, nova visão imprecisa, leve e fugitiva aparição. Heredia era destronado por Verlaine" (GANS, 1921, s/p).

Gans (1921) seguiu louvando a nova estética que deixou de lado a "carpintaria métrica" para dar ao verso maior liberdade de expressão. Como se vê, era uma crítica menos ácida ao passado, até porque muitos dos parnasianos estavam presentes e era de camaradagem que se fazia as 
relações sociais. Não havia o distanciamento ruidoso do passado. As casas, os salões, as repartições, os teatros - nos espaços públicos e privados os mundos se encontravam a todo instante, fazendo com que as relações fossem feitas por respeito, mesmo que uma ou outra vez as discussões pudessem ou parecessem sair do controle.

Dessa forma, tendo em mente as relações mais cuidadosas entre o passado e o presente, parece esclarecedor um artigo de Anaud Pierre (s/d) presente no arquivo de Adelino Magalhães. Nele há, mais uma vez, a diferenciação entre o grupo do Rio e o de São Paulo, feita através da figura de Manuel Bandeira. $O$ artigo começa com uma citação feita por Adelino Magalhães de que o Modernismo teria se imposto no Rio de Janeiro se lá não tivesse a poderosa "companhia". Adelino Magalhães referia-se à discussão que tivera, em 1920, com Bandeira em um bonde de Santa Teresa onde ambos moravam. Os dois se conheciam da casa de Gilka Machado; quando Adelino Magalhães criticou os livros ainda por demais sentimentais de Ribeiro Couto, Bandeira, muito amigo daquele, não mais fez camaradagem com Adelino Magalhães. Interessante notar que o mesmo Ribeiro Couto participou de muitas palestras das "Vesperais Literárias", bem como de reuniões do C.C.B.

Era dessa forma que os grupos formavam-se e desfaziam-se. As relações de Adelino Magalhães sempre foram mais próximas a Murilo Araújo, Andrade Murici, Gilka Machado, Tasso da Silveira e Nestor Vítor. Este grupo já visava novas tendências literárias, ainda que não fosse tão atuante como o grupo de Renato de Almeida, Ribeiro Couto e Ronald de Carvalho, ligados mais aos paulistas - sem mencionar que o grupo de Adelino Magalhães manteve-se fiel à tradição literária, como se pode ver nas "Vesperais Literárias" e, mais tarde, de forma mais emblemática, no Centro de Cultura Brasileira.

Interessante notar que, ao mesmo tempo em que Adelino Magalhães fazia suas "Vesperais Literárias" homenageando os poetas mortos, em outro local público, no Fluminense Football Club, o aclamado escritor Coelho Neto fazia uma festa artística ao avesso das da Biblioteca Nacional. $\mathrm{Na}$ vesperal de Coelho Neto, o poeta homenageado era Guilherme de Almeida. Mesmo não podendo dizer que Almeida tenha sido um grande realizador da proposta modernista, fato é que ele tentou. Assim, mais uma vez o que se vê são grupos aparentemente antagônicos convivendo pacificamente entre si. São os interesses de permanente evidência no campo literário e a vontade de reconhecimento e prestígio que contribuem para esse jogo menos literário do que político.

Novamente, há um espaço entre as reuniões que aconteceram no dia 30 de julho e as próximas noticiadas, as do dia 20 de agosto. Não se sabe se houve uma interrupção proposital ou se as reuniões apenas não foram mais noticiadas. Nas revistas de maior circulação na época, Careta e Fon 
Fon, não existe nada a respeito; no arquivo de Adelino Magalhães também não há referência, levando a crer que não houve conferências naqueles dias. As "Vesperais Literárias" do dia 20 de agosto foram, nos mesmos moldes das anteriores, compostas de nomes mais tradicionalistas, representados por Francisca Júlia, ao lado dos nomes de Gonzaga Duque e Cruz e Souza, comentado por Tasso da Silveira, mais de acordo com os pressupostos inovadores. As próximas "Vesperais Literárias" ocorreriam em 3 de setembro de 1921. O formato continuava o mesmo -os poetas homenageados seriam Marcello Gama, Auta de Souza, Antonio Lobo e Alphonsus de Guimaraens. De novidade, surge a figura de Jackson Figueiredo, crítico literário de militância católica. A amizade entre Figueiredo e Magalhães levou muitos críticos a julgar erroneamente a posição desse último, vinculando-o à ideologia católica. Vale ressaltar, uma vez mais, que Adelino Magalhães nega qualquer envolvimento ideológico quer no campo político quer no campo espiritual; posso até arriscar dizer que Adelino Magalhães afasta-se de qualquer vínculo também no campo literário.

Por fim, nas edições de número 692 da Revista Careta, de 24 de setembro de 1921, e de número 693, de 1 de outubro de 1921, o que se vê são as últimas notas a respeito das "Vesperais Literárias", as quais foram realizadas com grande sucesso de público durante o inverno tropical do Rio de Janeiro. Ambas as notas são cravejadas de elogios ao seu idealizador e a todos que participaram quer como palestrantes, quer como homenageados ou, ainda, como público que tornou possível tamanho evento. Nessas duas notas finais, maiores do que as outras anteriores, há um balanço geral do que foram realmente as "Vesperais Literárias", ou seja, qual espírito os donos da festa quiseram imprimir naqueles encontros festivos.

Vale salientar que a insistência pelos adjetivos "novos" e "modernos", que sempre acompanhavam os nomes dos realizadores das palestras, corresponde à imagem que eles próprios queriam passar: a de modernos que, não obstante, não se esqueciam do passado. Isso posto, percebe-se que tanto para Adelino Magalhães quanto para os demais organizadores o peso da tradição não incomodava, uma vez que, para eles, o reconhecimento dessa tradição não precisaria necessariamente rimar com atraso. Por conta disso, puderam fazer uma visita menos crítica ao passado literário.

A nota do dia 24 de setembro, no Careta, dia da última palestra, demonstra a necessidade da continuação de tão importante evento. $O$ texto traz pontos que merecem destaque: o primeiro diz respeito às homenagens aos poetas de linhagem simbolistas, os quais, por sua importância, não deveriam e nem poderia ser esquecidos; o segundo momento ressalta a importância da tradição literária que, mesmo distante das novidades pungentes, merece consideração; o terceiro ponto talvez seja o mais emblemático daquilo que 
se vem mostrando ao longo dos estudos das "Vesperais Literárias", do grupo de Adelino Magalhães e das redes de sociabilidade dos literatos do Rio de modo geral: qual seja, o trânsito de todos esses atores pelas diversos espaços públicos e privados que eles compartilhavam. Diz a nota:

Além disso, pondo-se de parte, Adelino apresentou ao grande público raras organizações literárias de moços, de novos verdadeiramente como Murilo Araujo, Tasso da Silveira, Perillo Gomes, Andrade Muricy, após outros mais velhos, muito dos quais já sobejamente conhecidos do público que se interessa por essas coisas. (REVISTA CARETA, 1921, s/p)

Chega-se, por fim, à última nota, dando por encerradas as tardes literárias da Biblioteca Nacional. Elas só retornariam a acontecer no ano de 1923, quando foi inaugurado oficialmente o C.C.B. Nesse contexto, as "Vesperais Literárias" tornam-se um evento dentro dessa agremiação cujo programa não só abrange o campo literário, mas a cultura nacional, de modo bastante amplo.

Retomando o artigo, já mencionado anteriormente, de Nestor Vítor (1972), o qual faz um apanhado geral do que representava aquelas "Vesperais Literárias" - $o$ autor detém sua atenção em dois pontos que acompanham a visão de arte de Adelino Magalhães: a querela infundada entre os "novos" e os "velhos" e entre a tradição e a inovação. Vítor (1972, p.451) analisa que as "Vesperais Literárias" merecem a simpatia porque não fazem "política literária na escolha das individualidades". Ademais, considera-se o papel do organizador, Adelino Magalhães, era o de prestar legítimo serviço à cultura do país. A análise de Vítor (1972), portanto, coloca em evidência a dinâmica entre o novo e o velho para Magalhães.

Resgatando prosadores e poetas, como parnasianos e realistas, ou outros menos compreendidos como os simbolistas - ou, ainda, os escritores regionalistas, criticados, muitas vezes, pelos modernistas paulistas -, as "Vesperais Literárias" cada vez mais se harmonizavam com seu criador. 0 velho e o novo, o antigo e o moderno, o conservadorismo e o progressismo, a tradição e a modernidade, pontos de convergência entre Adelino Magalhães e seu espírito inovador, entre o homem que vê o passado e que se projeta para o futuro.

As "Vesperais Literárias" tentam agrupar essa ideia de tradição e modernidade, entre os que foram e aqueles que estão chegando. Tudo isso é resumido por Vítor $(1972$, p.451) como um total desprendimento de Magalhães quanto ao critério de escolha dos nomes, "sem que a escola a que 
tenham pertencido os houvesse recomendado ou não recomendado, mas apenas o seu valor".

Sobre esse fato, Vitor (1972) argumenta que de todos os nomes que participaram das "Vesperais Literárias", apenas Tasso da Silveira, Brenno Arruda, Andrade Muricy e Claudio Ganns se mostraram contrários aos velhos processos: o naturalismo e o parnasianismo; ele acrescenta que, dentro os outros, dois, pelo menos (Agripino Grieco e Rodolfo Machado) lançaram sobre os acadêmicos (alguns dos quais estavam presentes) juízos e epítetos nada lisonjeiros.

Nessa linha de argumentação, é possível entender a distância entre as "Vesperais Literárias" e os artigos de "Mestres do Passado". Ambos foram confeccionados sob o signo ideológico de seus realizadores e de seus projetos ora próximos ora totalmente opostos. As palestras promovidas por Adelino Magalhães, exaltando os mestres do passado, exemplificam o lugar da tradição para esse grupo. Ao resgatar nomes esquecidos desprezados pelos vanguardistas, as "Vesperais Literárias" promovem a discussão do antigo e do novo. Assim, é interessante notar que o debate modernista já existia no Rio de Janeiro e que, para o grupo que gravita ao redor de Adelino Magalhães, a revolução pela inovação poderia ser feita sem que as tradições fossem completamente abandonadas.

\section{REFERÊNCIAS}

ARNAUD, Pierre. Bandeira e o grupo do Rio. Arquivo Adelino Magalhães, s/d.

As conferências dos Novos. Revista Careta, Rio de Janeiro, ano 16, n. 686. Disponível em <www. bn.br/periodicos>. Acesso em: 16 nov. 2014.

As palestras dos Novos. Revista Careta, Rio de Janeiro, ano 16, n. 677, 11 jun. 1921. Disponível em <www.bn.br/periodicos>. Acesso em: 16 nov. 2014.

BRITO, Mário da Silva. História do Modernismo Brasileiro - Antecedentes da Semana de Arte Moderna. Rio de janeiro: Civilização Brasileira, 1974.

BROCA, Brito. Quando teria começado o Modernismo? Arquivo Adelino Magalhães, s/d.

Festa da Arte. Revista Fon Fon. Rio de Janeiro, ano 15, n. 26, 25 jun. 1921. Disponível em <www.bn.br/periodicos>. Acesso em: 16 nov. 2014. 
GANS, Claudio. Raul Pederneiras. Fon Fon, ano 15, n. 32, 30 jul. 1921. Disponível em <www. bn.br/periodicos >. Acesso em: 16 nov. 2014.

Homenagem a Poetas Mortos. Revista Careta, Rio de Janeiro, ano 14, n. 638, 23 jul. 1921. Disponível em <www.bn.br/periodicos>. Acesso em: 16 nov. 2014.

MAGALHÃES, Adelino. Obras Completas. Aguilar Editora: Rio de janeiro, 1963. . Conversa com Adelino Magalhães. Entrevista a Waldir Ribeiro. Jul. 1953. Arquivo Adelino Magalhães.

MARTINS, Wilson. História da Inteligência Brasileira. Vol. VI. São Paulo: Cultrix/Edusp, 1978.

MURARI, Luciana. Uma modernidade às avessas? 'Progressistas' e 'Conservadores' na literatura brasileira da Belle Époque. Literatura, Arte e Saberes. ENCONTRO REGIONAL DA ABRALIC, 11., 24, 25 e 26 jul. 2007. Universidade de São Paulo. Anais... Disponível em < http://www.abralic. org.br/anais/enc2007/anais.html>. Acesso em 16 nov. 2014.

O Momento Intelectual. Revista Careta, Rio de Janeiro, ano 14, n. 679, 25 jun. 1921. Disponível em <www.bn.br/periodicos>. Acesso em: 16 nov. 2014.

O Vesperal do Fluminense. Rio de Janeiro, ano 14, número 685, 6 ago. 1921. Disponível em <www.bn.br/periodicos>. Acesso em: 16 nov. 2014.

Revista Careta, Rio de Janeiro, ano 19, n. 692, 24 set. 1921. Disponível em <www.bn.br/periodicos>. Acesso em: 16 nov. 2014.

Vesperal Literária. Fon Fon, ano 14, n. 32, 30 jul. 1921. Disponível em <www.bn.br/periodicos>. Acesso em: 16 nov. 2014.

VITOR, Nestor. "Um pouco da crônica da vida literária". In: Obra Crítica. Curitiba: Secretaria da Cultura e do Esporte, 1972. p.449-452.

Submetido em: 25/07/2014

Aceito em: 22/10/2014 